\title{
Magnitude of crustal extension across the northern Basin and Range province: constraints from paleomagnetism
}

\author{
Nicholas L. Bogen ${ }^{1, *}$ and Richard A. Schweickert ${ }^{2}$ \\ 'Departmem of Geological Sciences, University of Michigan, Ann Arhor. MI 48109 (U.S.A.) \\ 'Mackar' School of Mines, University of Nevada at Reno, Reno, NV 89557 (U.S.A.)
}

Received December 8, 1984; revised version received March 30. 1985

\begin{abstract}
The magnitude of crustal extension across the northern Basin and Range province is a matter of longstanding controversy; estimates range from 10 to $300 \%$. Recently published estimates of extension across the southern Basin and Range province $\left(36^{\circ} \mathrm{N}\right)$ are in the range of $80-100 \%$. Thus, the larger values suggested for the northern part of the province $\left(40^{\circ} \mathrm{N}\right)$ seem to require substantial counterclockwise rotation of the Sierra Nevada during Tertiary extension. Paleomagnetic data from the range, however, limit rotation to $4 \pm 10^{\circ}$ at the $95 \%$ confidence level. These limits. combined with estimates of extension near the Garlock fault. allow severe constraints to be placed on the magnitude of extension across more northerly parts of the province. We conclude that the maximum extension at $40^{\circ} \mathrm{N}$ is about $50 \%$ and that values of $39+12^{\circ}(188 \pm 43 \mathrm{~km})$ are likely.
\end{abstract}

\section{Introduction}

The continental crust beneath the Basin and Range province (Fig. 1) has undergone a large amount of extension during Cenozoic time and extension is continuing at present. The magnitude of extension is not well known. however, particularly in the northern part of the province; estimates range widely from 10 to $300 \%$. More precise estimates are required to understand the structural evolution of the Basin and Range province and, in general, the uplift, subsidence and rifting of extended continental lithosphere. In contrast, the magnitude of shortening strains across large regions of the crust have been known for some time in at least a few areas, for example. the IdahoWyoming and southern Canadian overthrust belts $[1,2]$. Yet, few similar data have been available for regions characterized by extensional strains, despite the importance of such strains in studies of continental basin and plateau formation [3].

Early estimates of the magnitude of crustal extension across the northern part of the Basin and Range province were based largely on simple models of crustal structure involving a large num-

* New address: Woodward-Clyde Consultants, 201 Willowbrook Boulevard, P.O. Box 290. Wayne. NJ 07470. U.S.A. ber of north-striking, planar normal faults. In such models, reasonable dip-slip displacements on the faults yield values of extension across the entire province of 10-20\% [4-7]. Hamilton and Myers [8] pointed out that listric normal faults with the same throw as planar faults would produce greater extension and they speculated that as much as $300 \%$ extension might have occurred across the northern Basin and Range. More recently, Wernicke [9] and Allmendinger et al. [10] have demonstrated the existence of low-angle normal faults in the northern Basin and Range, but neither the number of these faults nor their displacements are well known. To determine the magnitude of extension across the Basin and Range from crustal structure alone, it would be necessary to know the location, dip and displacement of all of the normal faults.

Recently, Wernicke et al. [11] showed that there has been a minimum of $65 \%(140 \mathrm{~km})$ of east-west extension across the southern part of the Basin and Range, just north of the Garlock fault (Fig. 1). They compared the distances between various geologic features north of the fault with the distances between correlative features to the south where little or no extension has occurred since the end of Miocene time. Their result is the first estimate of extension in the region that is not tied to a model 


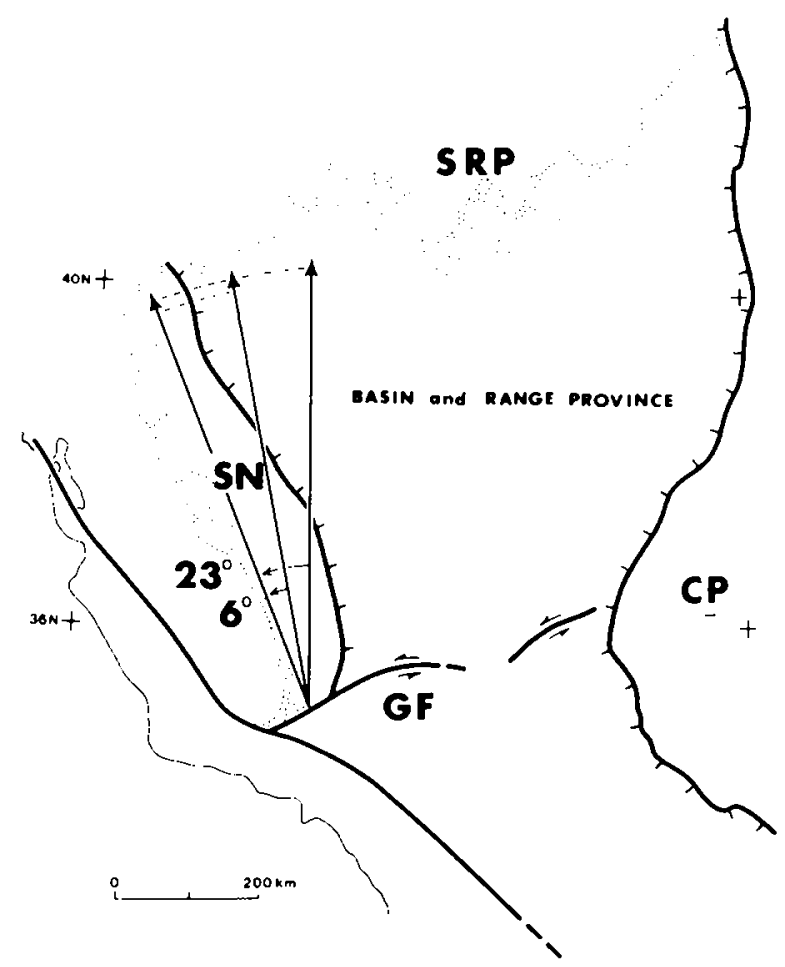

Fig. 1. Generalized map of the Basin and Range province. bounded by the Sierra Nevada ( $S N$ ). Snake River plain ( $S R P$ ). Colorado plateau (CP) and Garlock fault $(G F)$. A rotation of the Sierra Nevada block about a pole shown here at its southern end (the location is not critical) of $23^{\circ}$ counterclockwise would cause $185 \mathrm{~km}$ more east-west extension at $40^{\circ} \mathrm{N}$ than at $36^{\circ} \mathrm{N}$. Paleomagnetic data, however, allow countercleckwise rotation up $106^{\circ}$. which would produce at most $48 \mathrm{~km}$ more east-west extension at $40^{\circ} \mathrm{N}$ than at $36^{\circ} \mathrm{N}$.

of the crustal structure.

The width of the Basin and Range province increases from about $325 \mathrm{~km}$ at $36^{\circ} \mathrm{N}$ to about 680 $\mathrm{km}$ at $40^{\circ} \mathrm{N}$ (Fig. 1). This observation led Hamilton and Myers [8] to suggest that extension in the north has been far greater than in the south. They noted that such differential extension would require the northern Sierra Nevada to have moved westward more than the southern part of the range. resulting in a significant counterclockwise rotation (Fig. 1). Their suggestion seems reasonable in light of paleomagnetic evidence of rotations in other regions of far-western North America during Tertiary time, although these rotations are generally considered to have occurred in a clockwise direction [12-14]. In the following, we use paleomagnetic data from the Sierra Nevada and Colorado plateau to test the hypothesis that the
Sierra Nevada has rotated counterclockwise. From this test, we are able to constrain the magnitude of crustal extension across the northern Basin and Range province. A similar method relating block rotation to extension has been applied by Le Pichon and Angelier [15] to estimate the extension across the Aegean Sea, although they did not use paleomagnetic data to constrain the accompanying rotation of the Aegean arc. Frei et al. [16] also have studied the rotation of the Sierra Nevada in conjunction with rotations of other crustal blocks to the northwest, including the Klamath Mountains and Oregon Coast Range. Their principal concern was the paleogeographic and tectonic evolution of the continental margin during Cenozoic time but also included the westward movement of the Sierra Nevada block. In contrast, the main purpose of this study is to determine some of the large-scale structural properties of extending continental crust and therefore, our methods, assumptions and data are different from and independent of theirs. Yet, we note that our main conclusion regarding the magnitude of extension across the northern part of the Basin and Range province is not substantially different and the two approaches are mutually supportive, in large part.

\section{Paleomagnetism}

Paleomagnetic data have been collected from five formations in the western Sierra Nevada metamorphic belt (Fig. 2). The formations range in age from Mississippian to Late Jurassic; four of the units are volcanic and one is a mafic dike swarm. In the far-northern Sierra Nevada, the Mississipian Taylor and Permian Reeve Formations record northwesterly, normal magnetizations based on plots of stepwise demagnetization data [17]. Linear trajectories on vector-endpoint diagrams indicate that a single component is present. Formation mean directions and paleomagnetic pole positions are listed in Table 1. Similar magnetization directions are present in three Jurassic formations in the central part of the western belt, including the Lower Jurassic Penon Blanco Formation, the Callovian-Oxfordian Logtown Ridge Formation and the Oxfordian Sonora dike swarm (Table 1, [18]). These formation means were also determined by regression analysis of vector end-point diagrams, largely from thermal- 


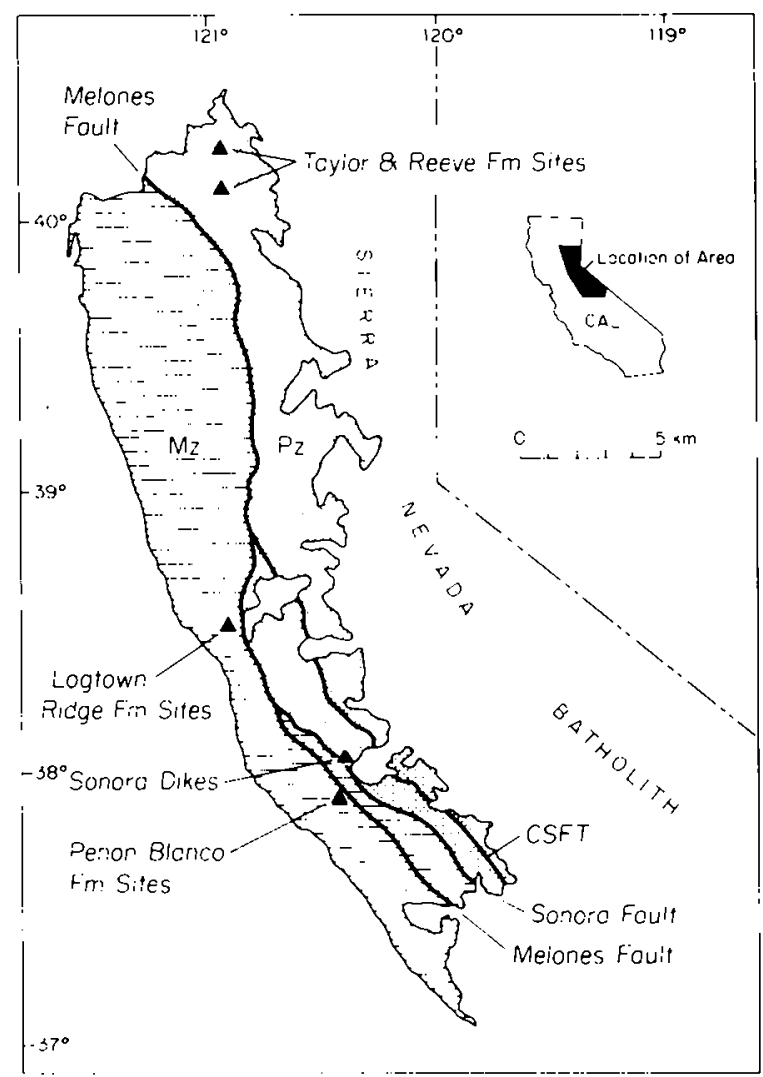

Fig. 2. Paleomagnetic sampling sites in the western metamorphic belt of the Sierra Nevada. California. Taylor and Recve Formation sites are from [17] and the remainder are from [18]. $M z$ and $P_{z}$ indicate Mesozoic and Paleozoic rocks, respectively.

demagnetization data.

Thermal demagnetism studies revealed a broad range of unblocking temperatures for each of the five formations. The intensity of magnetization fell to $10 \%$ of the natural remanent magnetization between 400 and $565^{\circ} \mathrm{C}$ suggesting that the remanence is carried by magnetite [17.18]. Vector endpoint diagrams indicate that the northwesterly magnetization is the sole component present in the Reeve. Taylor and Penon Blanco Formations whereas, the Logtown Ridge Formation and Sonora dike swarm yielded an additional component between 500 and $565^{\circ} \mathrm{C}$ directed toward the southeast $[17,18]$. The southeasterly component is nearly antipodal to the ubiquitous northwesterly magnetization after correction for tilts due to folding and therefore probably predates the Nevadan orogeny. The Logtown Ridge Formation and
Sonora dikes bear no marked cleavage or foliation in contrast to the other units which yielded only a single component of magnetization.

Demagnetization studies of the Reeve and Taylor Formations in alternating fields (AF) indicate that the remanence is of low coercivity with stable end-point directions obtained between 15 and $30 \mathrm{mT}$ [17]. AF demagnetization did not break down the remanence of most samples of the three Jurassic units, however, and thus, thermal demagnetization was employed.

Negative fold tests from both the northern and central Sierra and a conglomerate test of pillow breccia from the Logtown Ridge Formation indicate that the northwesterly magnetization is secondary $[17,18]$. There is no firm upper limit on the age of magnetization yet. all of the units were folded and metamorphosed to low-greenschist facies during the Late Jurassic Nevadan orogeny, the youngest structural-metamorphic event to have occurred in the region and the only such event to have affected all of the units studied [19]. We suggest, as did Hannah and Verosub [17]. that the secondary magnetizations formed during the Nevadan metamorphic culmination, after folding but during final development of the foliation. This point is discussed further below.

The Nevadan orogeny is one of the most tightly bracketed deformational-metamorphic events known. Folded strata are as young as early Kimmeridgian and folds and cleavages are cut by plutons as old as late Kimmeridgian [19.20]. The metamorphic culmination is late tectonic and therefore is of late Kimmeridgian age, although it may have extended into the early Tithonian Age as well. If the correlation of the secondary magnetizations with Nevadan metamorphism is correct. then the magnetizations are also of late Kimmeridgian or early Tithonian age.

The five formation mean directions yield an average direction of $D=330^{\circ} . I=59^{\circ}$ and a paleomagnetic pole position at $67^{\circ} \mathrm{N}, 161^{\circ} \mathrm{F}$ and $\alpha_{95}=6.5^{\circ}$. These averages are based on 157 samples distributed among 18 sites $[17,18]$. Because the sites are as much as $200 \mathrm{~km}$ apart, however, it is necessary to recalculate the data at a common point, located arbitrarily at $39^{\circ} \mathrm{N} .239^{\circ} \mathrm{E}$. Magnetization directions were calculated from each of the pole positions listed in Table 1 and their mean is $D=333^{\circ} . I=59^{\circ}$ and $\alpha_{4 \varsigma}=5.0^{\circ}$. 
TABLF: 1

Formation mean directions and paleomagnetic pole positions

\begin{tabular}{|c|c|c|c|c|c|c|c|c|}
\hline$R,(N)$ & $D$ & $I$ & $k$ & $\alpha_{45}$ & $\lambda^{\prime}$ & $\phi^{\prime}$ & $d m$ & $d p$ \\
\hline \multicolumn{9}{|c|}{ Logtonn Ridge Formation $\left(38.5^{\circ} \mathrm{N}, 239.1^{\circ} \mathrm{E}\right)$} \\
\hline $4 / 12$ & 336.4 & 65.3 & 132 & 6.1 & $71^{\circ} \mathrm{N}$ & $183^{\circ} \mathrm{I}$ & 10 & 9 \\
\hline \multicolumn{9}{|c|}{ Sonora dike swarm $\left(38.0^{\circ} \mathrm{N}, 239.4^{\circ} \mathrm{E}\right)$} \\
\hline $3 / 6$ & 324.3 & 60.0 & 313 & 4.6 & $63^{\circ} \mathrm{N}$ & $165^{\circ} \mathrm{E}$ & 7 & 5 \\
\hline \multicolumn{9}{|c|}{ Penon Blanco Formation $\left(38.0^{\circ} \mathrm{N}, 239.4^{\circ} \mathrm{E}\right)$} \\
\hline $3 / 3$ & 322.3 & 53.2 & 240 & 5.2 & $59^{\circ} \mathrm{N}$ & $154^{\circ} \mathrm{E}$ & 8 & 6 \\
\hline \multicolumn{9}{|c|}{ Reeve Formation $\left(40.2^{\circ} \mathrm{N}, 239.1^{\circ} \mathrm{E}\right)$} \\
\hline 52 & 339.8 & 53.8 & 9.3 & 6.8 & $73^{\circ} \mathrm{N}$ & $136^{\circ} \mathrm{E}$ & & \\
\hline \multicolumn{9}{|c|}{ Taylor Formation $\left(40.2^{\circ} \mathrm{N}, 239.1^{\circ} \mathrm{E}\right)$} \\
\hline 53 & 329.6 & 60.3 & 11.5 & 6.0 & $67^{\circ} \mathrm{N}$ & $162^{\circ} \mathrm{E}$ & & \\
\hline \multirow[t]{2}{*}{ Mean direction } & 330.4 & 58.7 & 159 & 5.0 & & & & \\
\hline & & & $\kappa$ & $A_{9 \varsigma}$ & & & & \\
\hline Mean pole position & & & 93 & 6.5 & $67^{\circ} \mathrm{N}$ & $161^{\circ} \mathrm{E}$ & & \\
\hline Reference pole & & & & 7.5 & $64^{\circ} \mathrm{N}$ & $144^{\circ} \mathrm{E}$ & & \\
\hline
\end{tabular}

logtown Ridge Formation, Sonora dike swarm and Penon Blanco Formation from [18]: Reeve and Taylor Formations from [17]. Formation names arc followed by their present coordinates. $R_{3}$ is the ratio of sites averaged to those collected; $N$ is the number of samples averaged; $D, I=$ declination and inclination (degrees); $K, \alpha_{95} . K$. A As are statistical parameters of Fisher [34]: $\lambda^{\prime}$, $\phi^{\prime}=$ latitude and longitude of the paleomagnetic pole: $d m, d p=$ semi-angles of the oval of $95 \%$ confidence about the paleopoles. See text for source of reference pole.

The net rotation of the Sierra Nevada since Late Jurassic time may be determined by comparison of the mean Sierran pole with a coeval pole from the craton. There are three determinations of the North American paleomagnetic pole for Kimmeridgian to early Tithonian time. Two are from redbeds of the Morrison Formation [21] and one is from volcanic rocks in the Canelo Hills, Arizona [22]. The three poles are distinct at the $95 \%$ confidence level and have been used to determine the mean Late Jurassic pole position of North America. along with other older and younger poles (e.g. [23-26]). The two Morrison Formation poles and the Canelo Hills pole are the closest in age to the Nevadan metamorphism available and their mean is listed in Table 1 and shown in Fig. 3. The restricted choice of reference poles was made in order to avoid measuring an apparent rotation resulting from a small 'difference in age between the mean Nevadan and North American reference poles.

The rotation of the Sierra Nevada may be determined by comparing the observed formation mean direction with that expected from the reference pole [13.27]. The rotation about a vertical axis, $r$, is the difference between the observed and expected declinations; for the Sierra Nevada, $r=4$ $\pm 10^{\circ}$ at the $95 \%$ confidence level. The maximum permissible rotations at the $95 \%$ confidence level are therefore $-6^{\circ}$ (counterclockwise) and $14^{\circ}$ and the minimum is zero.

The paleomagnetic data indicate that the Sierra Nevada has rotated little or not at all since Late Jurassic time and the suggestion of a large counterclockwise rotation to accommodate a large difference in extension between the southern and northern parts of the Basin and Range province is not supported by the data $[17,18]$. Other

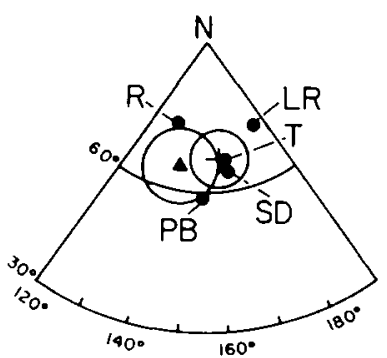

Fig. 3. Paleomagnetic pole positions (circles) from the Sicrra . Nevada of probable late Kimmeridgian to early Tithonian age and their mean (cross) with a circle of 95\% confidence of $6.5^{\circ}$. The reference pole for stable North America (triangle) is the mean of threc nearly coeval poles, two from the Morrison Formation, Colorado [21] and one from the Canclo Hills, Arizona [22]. 
paleomagnetic studies of Upper and Lower Cretaceous rocks of the Sierra Nevada batholith and the Upper Cretaceous Great Valley Group also indicate little or no rotation of the block [16.28-30]. lending strong support to the assumption that the Nevadan pole is of Kimmeridgian to early Tithonian age, not younger. Cretaceous plutons that might have been responsible for the remagnetization are several tens of kilometers distant from all the sampling sites and span a broad range of ages. If these plutons had remagnetized the metaigneous rocks, we would expect to see their polo positions strung out along the Cretaceous portion of the North American polar wander path rather than clustered around the Late Jurassic portion. Thus, the data from the five formations discussed herein is in accord with other pubiished studies but, also yields tighter constraints on the magnitude of allowable rotations. All of the data taken together, furthermore, severely restrict the possibility of large equal but opposite rotations since Late Jurassic time.

The maximum counterclockwise rotation allowed by the data, $6^{\circ}$, about a pivot point south of the range would produce only $48 \mathrm{~km}$ more westward translation of points at $40^{\circ} \mathrm{N}$ than at $36^{\circ} \mathrm{N}$ (Fig. 1), regardless of how far south the pivot is located. The much greater width of the northern Basin and Range ( $355 \mathrm{~km}$ wider) therefore cannot be due to much larger values of extension than in the south, but rather extension has affected a much broader region in the north than in the south. From the brackets on the amount of rotation that has occurred and the estimates of the amount of extension in the south [11], it is possible to determine the amount of extension across more northerly parts of the Basin and Range province.

\section{Extension}

Extension across the Basin and Range may be calculated as a simple elongation $(e)$ from the equation:

$e=\left(l-l_{0}\right) / l_{0}=\Delta l /(l-\Delta l)$

in which $l$ is the present width of the region, $l_{0}$ is the original width and $\Delta l$ is the change in width. We have chosen to calculate the extension in an east-west direction, following Wernicke et al. [11], because most of the normal faults within the re. gion strike roughly to the north and because rotation of the Sierra Nevada would cause extension in that direction, predominantly. The direction of maximum finite extension may be somewhat north or south of west, however, since the direction of extension in middle Miocene time may have been about $22^{\circ}$ south of west and the present direction is about $25 \pm 20^{\circ}$ north of west [31]. Our estimate of the extension may be less than the maximum by a factor equal to the cosine of the angle between the two directions. For an angle of $25^{\circ}$ or less, the calculated extension would be $90 \%$ or more of the maximum. As we shall show, this uncertainty is much smaller than other uncertainties involved. In addition, we assume that the Basin and Range has extended in a continuous fashion from south to north and that there are no major east-west discontinuities between the Garlock fault and the Snake River plain (Fig. 1). The Sierra Nevada block is considered to have been essentially rigid. although any block embedded in a more or less continuous, solid medium such as the earth's crust may be expected to deform along its margins during rotation.

Equation (1) may be written to describe the extension at $36^{\circ} \mathrm{N}$ and $40^{\circ} \mathrm{N}$ respectively:

$e_{\mathrm{s}}=\Delta l_{\mathrm{s}} /\left(l_{\mathrm{s}}-\Delta l_{\mathrm{s}}\right)$

and:

$e_{\mathrm{n}}=\Delta l_{\mathrm{n}} /\left(l_{\mathrm{n}}-\Delta l_{\mathrm{n}}\right)$

These two equations may be related by a third derived from the paleomagnetic constraints on the rotation of the Sierra Nevada.

For no rotation:

$\Delta l_{\mathrm{n}}=\Delta l_{\mathrm{s}}$

and for $-6^{\circ}$ rotation:

$\Delta l_{\mathrm{n}}=\Delta l_{\mathrm{s}}+48 \mathrm{~km}$

Clockwise rotation of up to $14^{\circ}$ would reduce extension by a maximum of $112 \mathrm{~km}$, thus:

$\Delta l_{n}=\Delta l_{s}-112 \mathrm{~km}$

Substituting for $\Delta l_{n}$ in (3), we find that for the three possibilities considered, $0^{\circ},-6^{\circ}$ and $14^{\circ}$ rotation, respectively:

$e_{\mathrm{n}}=\Delta l_{\mathrm{s}} /\left(l_{\mathrm{n}}-\Delta l_{\mathrm{s}}\right)$

$e_{\mathrm{n}}=\left(\Delta l_{\mathrm{s}}+48\right) /\left(l_{\mathrm{n}}-\Delta l_{\mathrm{s}}-48\right)$

$e_{\mathrm{n}}=\left(\Delta l_{\mathrm{s}}-112\right) /\left(l_{\mathrm{n}}-\Delta l_{\mathrm{s}}+112\right)$ 
These relations also apply to rotations about a pivot to the north of the Sierra Nevada because they describe only the difference in westward translation between points at $36^{\circ} \mathrm{N}$ and $40^{\circ} \mathrm{N}$, not the magnitude of the translations. With further substitutions from (1) and the present widths of the province in the north $(680 \mathrm{~km})$ and south $(325$ $\mathrm{km})$, we solve explicitly for $e_{\mathrm{n}}$ in terms of $e_{\text {, for }}$ the three cases as above:

$e_{\mathrm{n}}=325 e_{\mathrm{s}} /\left(355 e_{\mathrm{s}}+680\right)$

$e_{\mathrm{n}}=\left(373 e_{\mathrm{s}}+48\right) /\left(307 e_{\mathrm{s}}+632\right)$

$e_{\mathrm{n}}=\left(213 e_{\mathrm{s}}-112\right) /\left(467 e_{\mathrm{s}}+792\right)$

Equations (10), (11) and (12) may be plotted on a graph of $e_{n}$ vs. $e_{s}$ (Fig. 4) where they appear as three curves of relatively low slope. The low slopes indicate that extension at $40^{\circ} \mathrm{N}$ is not very sensitive to relatively large uncertainties in the amount of extension at $36^{\circ} \mathrm{N}$. In addition, the curves have asymptotes that provide upper limits on the extension in the north regardless of its value in the south. For example, the maximum extension possible at $40^{\circ} \mathrm{N}$ given a rotation of $-6^{\circ}$ is $121 \%$ and the maximum with no rotation is $92 \%$. According to Wernicke et al. [11], the minimum value of $e_{4}$ is $65 \%$ and the likely value is between 80 and $100 \%$. The range of corresponding values for $e_{n}$ lies between the two upper curves (Fig. 4) if clockwise rotation is neglected. Clockwise rotation is allowed by the paleomagnetic data but would produce unacceptably small values of extension in the north for any case except unrealistically large extensions in the south or very small rotations. Clockwise rotations about a pivot to the north of the Sierra Nevada would lead to $112 \mathrm{~km}$ more westward translation of points at $36^{\circ} \mathrm{N}$ than at $40^{\circ} \mathrm{N}$, again resulting in unacceptably small values of extension in the north. Thus, if we accept the likely values of $e_{\text {, then }}$ extension at $40^{\circ} \mathrm{N}$ is $36 \pm 9 \%$ or $178 \pm 33$ $\mathrm{km}$.

Extension in the south is likely to be between 80 and $100 \%$ but could be higher. However, because the slopes of the curves in Fig. 4 are so low, the actual value of $e_{s}$ makes relatively little difference to the calculated value of $e_{n}$. For extensions in the south ranging from 80 to $130 \%$, the extension in the north is between 27 and $51 \%$ or $39 \pm 12 \%$, only slightly larger than the values derived if $e_{、}=80-100 \%$. Fig. 4 shows graphically

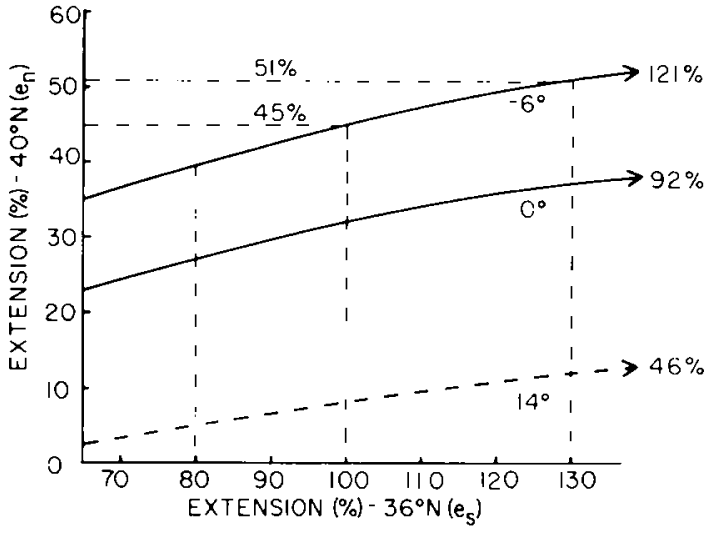

Fig. 4. East-west directed extensional strain across the Basin and Range province at $40^{\circ} \mathrm{N}\left(e_{n}\right)$ versus that at $36^{\circ} \mathrm{N}\left(e_{,}\right)$for rotations of $-6^{\circ}, 0^{\circ}$ and $14^{\circ}$. The curves asymptotically approach extensions of 121,92 and $46 \%$, respectively.

that the calculated extension in the north is not sensitive to relatively large uncertainties in the magnitude of extension in the south. This is a consequence of the small rotation allowed by the paleomagnetic data and the greater width of the northern Basin and Range province. The major source of uncertainty in $e_{\mathrm{n}}$ is the uncertainty in the amount of rotation, $\pm 10^{\circ}$. A larger counterclockwise rotation would produce a curve with proportionally steeper slope and thus the value of $e_{s}$ would become more important. Thus, given the paleomagnetic constraints suggested herein, extension at $40^{\circ} \mathrm{N}$ cannot greatly exceed $50 \%$, regardless of the location of the pivot point, unless extension across $36^{\circ} \mathrm{N}$ is far in excess of $130 \%$, which is unlikely.

Frei et al. [16] have suggested a more complicated movement scheme for the Sierra Nevada that links the rotation of the block to that of others to the north and employs a series of rotations about pivots both to the north and south of the range. Surprisingly, they proposed extension of $225 \mathrm{~km}$ at $41^{\circ} \mathrm{N}$, very close to that indicated herein. This suggests that the magnitude of extension across the northern Basin and Range is largely independent of the model employed, probably because the rotation is so small. We note. however, that it makes no difference how many pivot points or sequential rotations are involved in our model since we seek only to measure finite extension, which is independent of progressive, incremental extensions. 
The methods discussed above may be used to bracket the extension at any latitude within the Basin and Range province. Fig. 5 shows values calculated for an additional, intermediate region within the province. Because $\Delta l$ varies very little, the extension at any latitude is largely a function of the present width of the province. We note, however, that Fig. 5 says nothing about how the extension is distributed along a line of latitude; it only gives the total value.

The strains calculated above are close to those inferred from variations in crustal thickness across the region [7,8,33]. In the northern Basin and Range, the crust is about $28 \mathrm{~km}$ thick, on average, whereas the adjacent Sierra Nevada and Colorado plateau are about $42 \mathrm{~km}$ thick [32]. If the difference in thickness were due entirely to crustal extension (plane strain), a value of $50 \%$ would be implied $[7,8,31]$, within the range of values suggested herein. These results indicate that other

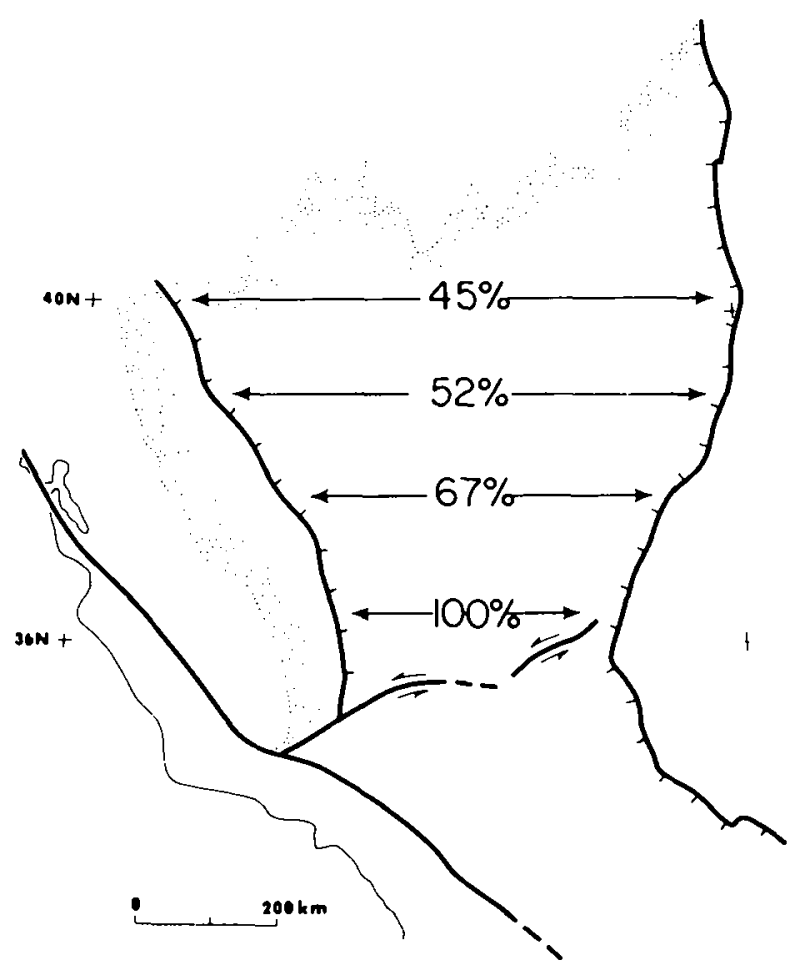

Fig. 5. Extensional strains at several latitudes across the Basin and Range province. Note that strain increases southward and is inversely proportional to the width of the province. See text for magnitude of uncertainties involved. processes that might lead to crustal thinning (e.g., phase changes), if active at all, played only a minor role in determining the present thickness of the crust beneath the northern Basin and Range province. In addition, the values of extension determined for the Basin and Range province, 50 to $100 \%$, are very close to those calculated for another active, intracratonic sedimentary basin, the Aegean Sea [15].

\section{Conclusions}

Paleomagnetic data from the Sierra Nevada and Colorado plateau indicate that their relative orientations have changed little since Late Jurassic time and, therefore, the northern and southern parts of the Sierra Nevada block have moved westward nearly equal distances during Tertiary extension. regardless of their true direction of maximum extension. Thus, the greater width of the northern Basin and Range province is due to the distribution of extension over a much broader region, not to larger values of extensional strain.

The paleomagnetic data and the geometry of the region allow us to relate extension in the north to that in the south where Wernicke et al. [11] have shown that values of $80-100 \%$ are likely. This analysis shows that there are upper limits on the extension in the north that are largely independent of extension to the south and of the rotational model employed, but depend critically on the magnitude of the rotation. If the rotation is very small as indicated by our data and those of others, then the upper limit on extension across $40^{\circ} \mathrm{N}$ is $121 \%$. regardless of the extension across the south. However, given the range of values proposed by Wernicke et al. [11] and constraints from crustal thicknesses, it seems likely that extension across $40^{\circ} \mathrm{N}$ is no more than $50 \%$ and is within the range of $39 \pm 12 \%(188 \pm 43 \mathrm{~km})$. These values are in accord with those inferred from variations in crustal thickness across the region and support the idea that crustal thinning has occurred largely by extension.

\section{Acknowledgements}

We thank reviewers $R$. Van der Voo and $K$. Coles for their comments and suggestions. 


\section{References}

1 F. Royse, Jr.. M.A. Warner and D.L. Reese, Thrust belt geometry and related stratigraphic problems, WyomingJdaho-northern Utah: deep drilling frontiers of the central Rocky Mountains, in: Rocky Mountain Assoc. Geol. Symposium Volume, pp. 41-54. 1975.

2 R.A. Price and 1..W. Mountjoy, Geologic structure of the Canadian Rocky Mountains between Bow and Athabasca Rivers-a progress report, in: Structure of the Southern Canadian Cordillera, J.O. Wheeler, ed.. Spec. Pap. Geol. Sox. Can. 6. 7 25, 1970.

3 D. McKenzic, Some remarks on the development of sedimentary basins, Earth Planet. Sci. I.et1. 40, 25-32.

4 G.A. Thompson. Problem of Late Cenozoic structure of the Basin Ranges. in: Int. Geol. Congr. Rep. 21 st Session, Part XVIII. pp. 62-68. 1960 .

5 G.A. Thompson and D.B. Burke. Rate and direction of spreading in Dixic Valley. Basin and Range province. Nevada, Geol. Soc. Am. Bull. 84, 627-632, 1973.

6 J.H. Stewart, Basin and Range structure-a system of horsts and grabens produced by deep-seated extension. (jeol. Soc. Am. Bull. 82, 1019-1043, 1971.

7 J.H. Stewart, Basin-Range structure in western North America: a review. in: Cenozoic Tectonics and Regional Geophysics of the Western Cordillera, R.B. Smith and G.P. Eaton, eds., Geol. Soc. Am. Mem. 152. 1-32, 1978.

8 W. Hamilton and W.B. Myers, Cenozoic tectonics of the western United States. Rev. Geophys. 4, 509-549, 1966.

9 B. Wernicke. Low-angle normal faults in the Basin and Range province: nappe tectonics in an extending orogen, Nature 291, 645-648, 1981.

10 R.W. Allmendinger. J.W. Sharp, D. Von Tish, L. Serpa, I. Brown, J.F. Oliver and S. Kaufman, COCORP scismic reflection data from the eastern Basin and Range, westcentral Utah. Geol. Soc. Am. Abstr. Prog. 15, 287, 1983.

11 B. Wernicke, J.K. Spencer, B.C. Burchfiel and P.L. Guth, Magnitude of crustal extension in the southern Great Basin, (jeology 10, 499-502, 1982.

12 M.E. Beck, Jr.. Discordant paleomagnetic pole positions as evidence of regional shear in the western Cordillera of North America, Am. J. Sci. 276, 694-712, 1976.

13 M.E. Beck, Jr., Paleomagnetic record of plate margin tectonic processes along the western margin of North America, J. Geophys. Res. 85, 7115-7131, 1980.

14 R.W. Simpson and A. Cox, Palcomagnetic evidence for tectonic rotation of the Oregon Coast Range, Geology 5. 585-589. 1977.

$15 X$. Le Pichon and $J$. Angelier, The Hellenic arc and trench systcm: a key to evolution of the eastern Mediterranean area. Tecionophysics 60. $142,1979$.

16 I..S. Frei. J.R. Magill and A. Cox. Paleomagnetic results from the central Sierra Nevada: constraints on reconstructions of the western United States, Tectonics 3, 157-177. 1984.

17 J.L. Hannah and K.L. Verosub. Tectonic implications of remagnetized upper Paleozoic strata of the northern Sierra Nevada, Geology 8. 520-524, 1980.
18 N.L. Bogen, D.V. Kent and R.A. Schweickert. Paleomagnetic constraints on the structural development of the Melones and Sonora faults, central Sierran foothills, California. J. Geophys. Res. 90. 4627-4638. 1985.

19 R.A. Schweickert. N.L. Bogen. G.H. Girty. R.E. Hanson and $C$. Merguerian. Timing and structural expression of the Vevadan orogeny, Sierra Nevada. California, Gcol. Soc. Am. Bull. 95, 967-979.

20 L.D. Clark, Stratigraphy and structure of part of the western Sierra Nevada metamorphic belt, California, U.S. Geol. Surv. Prof. Pap. 410,70 pp.. 1964.

21 M.B. Steiner and C.F. Helsley. Reversal pattern and apparent polar wander for the Late Jurassic, Geol. Soc. Am. Bull. 86, 1537-1543, 1975.

22 I..F. Kluth. R.F. Butler. I..E. Harding, M. Shufiquallah and P.E. Damon. Paleomagnetism of Late Jurassic rocks in the northern Canelo Hills, southeastern Arizona, J. Geophys. Res. 87, 7079-7086, 1982.

2.3 T.F. Smith and H.C. Noltimier, Paleomagnetism of the Newark trend igneous rocks of the north central Appalachians and the opening of the central Atlantic Ocean. Am. J. Sci. 279. 778-807, 1979.

24 C.G.A. Harrison and T. Lindh. A polar wandering curve for North America during the Mesozoic and Cenozoic, J. Geophys. Res. 87. 1903-1920, 1982

25 F. Irving and G.A. Irving, Apparent polar wander paths Carboniferous through Cenozoic and the assembly of Gondwana, Geophys. Surv. 5, 141-188. 1982.

26 R.G. Gordon, A. Cox and S. O'Hare. Paleomagnetic Fuler poles and the apparent polar wander and absolute motion of North America since the Carboniferous, Tectonics 3. $499-538.1984$.

27 H.H. Demarest, Error analysis for the determination of tectonic rotation from paleomagnetic data. J. Geophys. Res. $88,4321-4328.1983$.

28 C.S. Gromme, and R.I. Merrill, Palcomagnetism of late Cretaceous granitic plutons in the Sierra Nevada: further results, J. Geophys. Res. 70, 3407-3420, 1965.

29 C.S. Gromme, R.T. Merrill and J. Verhoogen, Paleomagnetism of Jurassic and Cretaceous plutonic rocks in the Sierra Nevada. California, and its significance for polar wandering and continental drift. J. Geophys. Res. 72. 5661-5684. 1967.

30 F.. A. Mankinen. Paleomagnetic evidence for deformation of the Great Valley sequence. California, U.S. Geol. Surv. J. Res. 6. 383-390, 1978.

31 M.L. Zoback and G.A. Thompson, Basin and Range rifting in northern Nevada: clues from a mid-Miocene rift and its subsequent offsets, Geology 6,111-116, 1978.

32 R.B. Smith. Seismicity, crustal structure and intraplate tectonics of the interior of the western Cordillera. in: (inozoic Tectonics and Regional Geophysics of the Western Cordillera, R.B. Smith and G.P. Faton. eds., Geol. Six. Am. Mem. 152. pp. 111-144, 1978.

3.3 G.A. Thompson. Cenozoic Basin and Range tectonism in relation to deep structure, in: Proc. 24th Int. Geol. Congr. pp. 84-90, 1972.

34 R.A. Fisher, Dispersion on a sphere, Prox. R. Sox. London Ser. A 217, 295-305, 1953. 